\title{
International Community Interventions in Somalia's Conflicts to Promote peace and Security: Amisom Case
}

\author{
Abdullahi Sh-Mohamed Hussein \\ Master of African Studies and International Relations, Graduate Institute of Social Science, Istanbul Ticaret University, Turkey
}

\begin{abstract}
Since the Somali government got independence in 1960, the international community intervention in Somalia was existed both politically military and humanitarian. Somalia has entered a new era in its contemporary history, which has taken on a regrettable and destructive character in the areas of security, peace and stability 1991 after collapse of Somali. Therefore. This research examines whether the African Union Mission in Somalia (AMISOM) has met its current strategic objectives and, if so, what impact it has had on Somalia's broader political and security dynamics. The organization is now in its eleventh year of operation. AMISOM is one of a larger group of international actors attempting to restore stability to the country. This constellation highlights the benefits and drawbacks of collaborations in modern peacekeeping missions. It also emphasizes the importance of good coordination among various actors, particularly the Somali government, the African Union (AU), the United Nations (UN), the European Union (EU), and some major bilateral partners, such as the United States and the United Kingdom. As a result, AMISOM is in an unfortunate position. This study will use the quantitative method of information conducted in the literature review and further discussion with Somali government officials Amisom and the other experts. Amongst the techniques that will be used in this study, will be the purposive sampling technique which will allow the researcher to select certain respondents according to their ability to give information. Therefore, the key informants will be purposively selected from various officials. The study will collect both primary and secondary data. Before conducting these interviews, the researcher will have to design an interview guide that will be used in directing the conversation towards the topic and issues involved in this research. The results will be presented in a Microsoft word document.
\end{abstract}

Keywords: Peacebuilding, Security, international community, Amisom, Somali National Army, Civil War, Conflict Resolution,

\section{INTRODUCTION}

A fter colonial era Several domestic armed conflicts have plagued in Africa. During the Cold War, the Horn of Africa was continually influenced by unexpected and sudden conflicts, tensions of ideological confrontations, regional disputes, cross-boundary deterioration and constant militarisation. the situation in the Horn of Africa were either a crisis zone or a mere battle ground between the United States and the Soviet Union. The two global influence powers (USA, USSR) were not only intensely engaged in the regional states' political and security affairs, but also consistently supported the escalation of a regional arms race in the Horn of Africa Sabala (2011: 98).

In the increasing waves of government oppositions during 1980s largely in the African continent it led the rise of the popular Somali armed opposition, this exploded into chaos, violence, and anarchy covered in the whole country. and it was later resulted the government collapse in 1991.

After the escalation of the Somali civil war, a series of Security Council resolutions including 733, 746, and diplomatic visits led to imposition of a ceasefire between the rival groups which opened channels of humanitarian aid supplies by 1992. Nonetheless, when Security Council adopted subsequent resolutions - calling the forceful disarmaments of clan militia- let the paralysis that the fighting imposed on UN, and the disastrous losses popularly known as 'Black Hawk Down' incident sealed the fate of UN operation by March 1995, leaving Somalia still in a state of violence and anarchy, Ibid.

In February 1991, the opposition groups announced the formation of a provisional government. They drew support from a particular sub-clan, and each clan exploited arms to advance their claims. This further increased the degeneration of all essential government services, which ceased operating, long before the war broke out. The international Community, such as Djibouti, the League of Arab States, the Organization of African Unity, the Organization of Islamic Co-operation, and the United Nations made several attempts to end the fighting in Mogadishu with no avail (Buzan, 1991).

The impacts of warring factions led to destruction of Somali agriculture, which resulted into malnourishment in large parts of Somalia. The general situation of the country worsened not only as the result of civil war, but also of its drought affects in Central and Southern Somalia that left hundreds of thousands starved. By 1992, an estimated 250,000 Somali died in this war, while double of that fled to Ethiopia, Kenya, Yemen, Djibouti, and Europe World Bank (2005). On top of total infrastructure destruction in the country, the Somali civil war reduced all economic activities into stand still with lowest subsistence agriculture, herding, and local trade. 
Furthermore, the post-UNOSOM armed conflict shifted to low concentration in nature, whereby local sub clans unreliably abandoning each other till neighboring countries with international community under the supports of UN forged central administration at Djibouti in 2000 (the Transitional National Government TNG), and in 2004 the (Transitional Federal Government TFG) at Kenya. By contrast, peace efforts in late 2004 paved the way for a new phase in the Somali civil war. One consequence of the signs of growing unification was that various militias were co-opted into larger guerrilla coalitions Buzan, (1991).

Accordingly, the Transitional Federal Government was not able to establish itself and split soon after its inception while still in Kenya. This caused into crisis which intensified in-order to bring the Transitional federal government of Somalia in Mogadishu the capital city which was controlled at that time the UIC insurgents. This made Ethiopian forces (in supported by US) invaded Somali in late 2006.

Hoahne, (2006) points out that this invasion installed the TFG in Mogadishu. The new leaders were confronted by a complex Islamic insurgency in the south part of Somalia. In 2008, TFG signed peace agreement with the Alliance for the Re-liberation of Somalia (ARS) in Djibouti. Under this agreement, Sheikh Sherriff Sheikh Ahmed the head of the main resistance group Union of Islamic Courts (UIC) during Ethiopian invasion in Somalia (who was once considered as Taliban like radicals by much of the west) became Somali president on 31 January 2009, Ibid.

Unfortunately, however, the agreement was not all inclusive; it saw splinters within Sheriffs camp. An off shoot from (UIC) named Hizb al-Islam, and "Al Shabaab" Islamist rejected his presidency, and continued resistance against any foreign troops stationed in Somalia. Hence, there are signs of an improved security situation in Somalia. Most notably, the external military intervention by AMISOM has reduced the threat from armed opposition Africa Research Bulletin, (2013).

In addition to the Al-Shabaab's threat, however, there are also signs of mistrust between Uganda who control Benadir (the main region of Somalia) from the group, Kenya and Ethiopia, who before joining the mission now freelanced outside AMISOM unilaterally in the Somalia armed conflict. Although Uganda is interested in a stable and strong state in Somalia, Kenya and Ethiopia have their own distinct agendas that are at odds with the political priorities of Kampala and the FGS. For example, there is evidence to show that they want to create buffer zones between the two countries from Somalia Eriksson $(2013,4)$.

Nonetheless, in the light of combined above mentioned obstacles against Amisom, the Amisom operation in Somalia makes this study imperative to undertake and evaluate the role and challenges faced the mission for promoting peace and security in Somalia.

\section{The Nature of Somalia's Conflict}

For many decades, the nature of Somali crisis has changed constantly within international context. It transformed from a civil warfare in the 1980s, through state collapse, clannism and warlords in the 1990s, and now to a conflict with global ideology underpinnings Mark \& Sally, (2010).

The Somali conflict was originally caused by dictatorial rule and opposition groups in 1991 and it became destructive with negative costs for the country's moral and social fabric, lately new actors emerged as the conflict intensified (Makhubela, 2010).

According to Imaana (2009), the Somalia conflict can be categorized into three types of modern war prospective as it unfolded since independence. The first type is common identity or value system despite Somalis having generally only one tribal grouping, there is a difference of between them as well. The Struggles to gain access to state power and resources have also driven some warlords and other armed groups to attempt takeovers, while others have fought for regional autonomy or even independent mini states.

The Role of Amisom Troops Towards Promoting Peace and Security in Somalia

The African Union Organization in Somalia (AMISOM) is a functioning regional peacekeeping mission run by the African Union with UN Security Council permission. Its responsibilities include assisting in the creation of a secure environment for humanitarian aid delivery, supporting transitional governmental structures, implementing a national security plan, training Somali security forces, and assisting in the implementation of a national security strategy. AMISOM also assists the Federal Government of Somalia's military in their fight against Al-Shabaab extremists as part of its mandate. Musoma, Albert Lusiola (2021).

The mandate of AMISOM has been extended every time it has been up for review, most recently in May 2019. The current mandate expires on May 31, 2020, with troop levels reduced to a maximum of 19,626 by February 28, 2020. The African Union's Peace and Security Council established AMISOM on January 19, 2007, with a six-month mandate. The mandate of the mission was approved by the United Nations Security Council on February 21, 2007. The UN Security Council has also approved subsequent six-monthly renewals of AMISOM's mandate by the African Union Peace and Security Council.

African Union Peacekeeping Forces influence over Somalia's political situation took a new turn. Uganda, particularly its leader president Yoweri Museveni, has become a force to reckon with when it comes to Somalia matters. At the beginning, Uganda has increased its influence on Somalia affairs, the western powers and other interested partners consider it the main player in the power game in the Horn of Africa nation, (www.somaliareport.com). Amisom force aim 
was helping Somali National Security Forces to push the Al Qaeda-affiliated terror group, Al-Shabaab, out of much of southern Somalia including the Capital city of Mogadishu and most major towns and cities. It has created a relatively secure environment which has allowed the Somali peace process to take root, and currently military component troops from Uganda, Burundi, Djibouti, Kenya and Ethiopia. However, the Ugandan troops are deployed in Sector one, which covers the regions of Banadir -included the capital city of Mogadishuand Lower Shabelle. Kenyan forces are responsible for Sector two including Lower and Middle Jubba. The third Sector of Bay and Bakool as well as Gedo Region comes under Ethiopian command, Djiboutian forces oversee Sector four which covers Hiiraan and Galgaduud Regions while Burundian forces oversee Sector five which covers the Middle Shabelle region. "https://amisom-au.org/missionprofile/military-component/,"

Challenges Faced the AMISOM Forces in Promoting Security in Somalia

AMISOM had made progress on its three current strategic objectives: reducing the threat posed by al-Shabaab and other armed opposition groups; providing security to support Somalia's political process and reconciliation efforts; and handing over security responsibilities to Somali security forces. We did notice, however, that the mission continued to confront significant problems and restrictions, implying that achieving an effective handover to Somali forces would not be simple or quick.

According to the study published in the Center for Strategic and International Studies, The AMISOM peacekeeping in Somalia have encountered major obstacles in their ways of reforming security and fighting terrorists. However, the main challenges faced AMISOM's peacebuilding task in Somalia signifies: the legacy of the October 1993 "Black Hawk Down" and Ethiopia's military campaign to control the region, particularly the Horn of Africa (Somalia); the African Union's capacity problems; the Nature of Somali conflict; and finding an appropriate exit strategy. The predictable results were a dangerously under-resourced operation that placed several thousand

\section{CONCLUSION}

Although, the international community intervention and management of conflicts in the horn of Africa had posed a major challenge to regional organizations, states, regional and the international community. A close examination of the study based on the guide reveals that the need to have intervention by international community, Amisom troops are one of the basic issues as far as the conflict situation in Somalia is concerned. In this regard, the findings show that both international community and AMISOM mission have contributed to solve unrest situations in Somalia by fighting back the terrorist groups and supporting the Somalia Military army.
In this research paper, the international Community and AMISOM interventions are to be justified not only when civilian populations are targeted, but also more broadly when conflict intensity has increased significantly. Military, economic and diplomatic interventions are main actors use to influence the outcomes of conflict. Therefore Unluckily, there are signs that neighboring relations are currently drifting away from such trust. The military involvement of Kenya, Uganda and Ethiopia have so far been with the consent of the Federal Government of Somalia (FGS), but it is now on the precipice of causing regional tensions as these states have different political visions for Somalia. However, any split in the political alignment poses a challenge for de-escalating the cycle of conflict.

Various forms of interventions affect conflict intensity differently, and distinct objectives of the same type of intervention have different results. Biased military interventions escalate conflict while neutral interventions have no significant effect. Biased diplomatic interventions that support both sides have no effect on conflict intensity, but if they are neutral, they can be associated with lower conflict intensity. The motivations of the actors did not seem to be causally linked to conflict intensity, specifically after the middle of the 1990s. Overall, the assumption that interventions promote peace is rejected. Instead, the peace objective may compete with other objectives in a gathering of external and internal actors' motivations and initiatives. However, these advancement among the Amisom Peacekeepers with SNF have positively affected the security of Nation and slowed its terror attacks and eventual spread to most parts of Somalia.

\section{REFERENCES}

[1] Africa Research Bulletin: Political Social and Cultural Series, Vol. 50, no.7 (2013) 19789.

[2] Buzan, Barry (1991). People, States and Fear: An Agenda for International Security Studies in post-Cold War Era (London: Harvester Wheat sheaf).

[3] Erickson, Mikael (2013). External intervention in Somalia's civil war: Security Promotion and National Interest? FOI-R--3687--SE (Swedish Defense Research Agency, November)

[4] Hohne, M. (2006). Political identity, emerging state structure and conflict in northern Somalia. The Journal of Modern African studies, 44 (3) 397-414.

[5] Imaana Laibuta, 2009: The Somalia Conflict and Its Effects in the Horn of Africa; Institute of Diplomacy and International Studies (IDIS), University of Nairobi

[6] LM Makhubela, 2010: conflict resolution in Somalia: learning from field mediation process.

[7] Mark Bradbury and Sally Healy; 2010: a brief history of the Somali conflict

[8] Mat, T. (1997). Social Research: Issues, Methods, and Process. London Buckingham: Open University Press.

[9] Musoma, Albert Lusiola (2021). Military diplomacy strategies applied by AMISOM in restoration of peace and security in the Horn of Africa. African Journal of Empirical Research, 2 (1), 41 55. DOI: https://doi.org/10.51867/ajer.v2i1.5

[10] Sabala, Kizito (2011;98). Regional and Extra-Regional Inputs in Promoting (in) security in Somalia, in (Eds) Sharamo, Roba and Mesfin, Berouk: Regional Security in the Post-Cold War Horn of Africa Pretoria: Institute for Security Studies, 2011 
[11] United Nations Security Council Resolution 1744 S/RES/1744(2007) (2007)

[12] United Nations Security Council Resolution 1772. S/RES/1772(2007) page 3. (2007)

[13] United Nations Security Council Resolution 1772. S/RES/1772(2007) (2007)

[14] United Nations Security Council Resolution 1801. S/RES/1801(2008) (2008)
[15] www.somaliareport.com; Uganda's growing influence on Somalia; retrieved on $24^{\text {th }} / 04 / 2014$

[16] "The situation in Somalia (2019)". 31 May 2019. Retrieved 12 July 2019.

[17] "69th meeting of the peace and Security Council". Agence de Presse Africaine. 22 January 2007. Archived from the original on 28 August 2007. Retrieved 9 February 2007.

[18] "https://amisom-au.org/mission-profile/military-component/" 